\title{
Monitoramento molecular de pacientes com leucemia mieloide crônica em uso de imatinib através da técnica de PCR quantitativo em tempo real Molecular monitoring of chronic myeloid leukemia patients treated with imatinib using real time PCR
}

\author{
Melissa P. Machado
}

Orientadora: Katia B. B. Pagnano

\section{Resumo}

A leucemia mieloide crônica (LMC) é uma neoplasia mieloproliferativa caracterizada pela presença do cromossomo Philadelphia $(\mathrm{Ph})$, resultado da fusão do gene abl e do gene bcr cujo produto é uma proteína de atividade de tirosina quinase, inibida pelo imatinibe. O imatinibe é hoje o tratamento de primeira linha da LMC, e o monitoramento molecular dos transcritos BCRABL é fundamental no acompanhamento dos pacientes e na detecção precoce da perda de resposta ao tratamento. O objetivo deste trabalho foi padronizar o método de PCR quantitativo (RQPCR) para o monitoramento molecular dos transcritos BCR-ABL de pacientes com LMC em tratamento com imatinibe. Foi utilizado o método Taqman e, como gene controle, o ABL. Foi criada uma curva standard com diluições de 108 a 103 de um plasmídeo com os transcritos b3a2 e b2a 2 e com ABL. As quantificações foram feitas em duplicatas. $\mathrm{O}$ threshold utilizado foi de 0,05 e a eficiência foi determinada em $99 \%$. Os resultados foram reportados como uma relação entre BCR-ABL/ABL. Para o valor de referência basal do laboratório foram analisadas trinta amostras de pacientes ao diagnóstico, e calculada a mediana, sendo esse valor de $83,66 \%$. Resposta molecular maior (RMM) foi definida como redução dos transcritos BCR-ABL em 3 log a partir do valor basal do laboratório. Os valores foram ajustados à escala internacional, usando-se um fator de conversão de 1.19. Após a padronização do método, foram avaliados sessenta pacientes com LMC, cujas amostras foram coletadas ao diagnóstico e a cada três meses. Respostas hematológica, citogenética maior e citogenética completa foram obtidas em 57 (95\%), 45 (75\%) e 38 (63\%) dos pacientes, respectivamente. Vinte e quatro de sessenta pacientes atingiram a RMM (40\%), numa mediana de 8,5 meses. A sobrevida global foi superior nos pacientes com RCC (100\%) versus pacientes sem RCC (77\%) em 48 meses. Pacientes com RCC e com RMM tiveram uma sobrevida livre de eventos superior em relação aos pacientes que não atingiram os dois tipos de resposta (100\% versus $60 \%$ respectivamente) $(p=0.007)$. Em resumo, neste estudo demonstramos o impacto prognóstico em atingir RCC e RMM e também a importância do acompanhamento molecular nos pacientes com LMC.

Palavras-chave: LMC; mesilato de imatinibe; PCR real-time.

\section{Abstract}

Chronic myeloid leukemia (CML) is a myeloproliferative disorder characterized by the presence of the Philadelphia chromosome $(\mathrm{Ph})$, the result of a bcr-abl gene fusion, the product of which is a protein with kinase activity that can be inhibited by imatinib. Imatinib is currently the first-line treatment of CML and molecular monitoring of BCR-ABL transcripts is essential to detect early loss of response to treatment. The aim of this study was to standardize the quantitative PCR (RQ-PCR) method for molecular monitoring of BCR-ABL transcripts in patients with CML treated with imatinib. Peripheral blood samples from chronic phase patients were collected for RQ-PCR at diagnosis and every three months after treatment with imatinib. The Taqman method was used for RQ-PCR. A standard curve was constructed with dilutions of 108 to 103 of a plasmid with the $\mathrm{b} 3 \mathrm{a} 2$ and $\mathrm{b} 2 \mathrm{a} 2$ transcripts and the $\mathrm{ABL}$ gene being used as the control gene. Duplicate runs were made. The threshold used was 0.05 and the efficiency was determined at $99 \%$. The results are reported as a BCR-ABL/ABL ratio (\%). For the reference baseline value of the laboratory, 30 samples from patients at diagnosis were quantified and the median value was calculated at $83.66 \%$. Major molecular response (MMR) was considered a three $\log$ reduction from the baseline value. MMR values were adjusted to international scale, using a conversion factor of 1.19. After standardization, the BCR-ABL levels of 60 chronic phase CML

Dissertação apresentada ao Centro de Hematologia e Hemoterapia - Universidade Estadual de Campinas

Correspondência: Katia B. Barbosa Pagnano

Hemocentro-Unicamp

Rua Carlos Chagas 480

13083-970 - Campinas-SP - Brasil

E-mail: kborgia@unicamp.br 
patients treated with imatinib were measured at diagnosis and then at every three months. Hematological, major cytogenetic and complete cytogenetic responses were achieved in 57 (95\%), 45 $(75 \%)$ and $38(63 \%)$ patients, respectively. Twenty-four out of 60 patients achieved a MMR (40\%) in a median time of 8.5 months. Overall survival was higher for patients with CCR (100\%) versus patients with no CCR $(77 \%-p=0.01)$ at 48 months. Patients with $\mathrm{CCR}$ and with MMR had a higher event free-survival rate compared to patients with CCR and no MMR ( $p=0.007)$. In conclusion, we demonstrated the prognostic impact of achieving CCR and a MMR and also the importance of molecular monitoring in the follow-up of CML patients.

Key words: CML; imatinib; real-time PCR

Avaliação: A Revista Brasileira de Hematologia e Hemoterapia $(\mathrm{RBHH})$ publica os resumos e abstracts de teses da área apresentados em entidades que tenham programas de pós-graduação reconhecidos pelo MEC/Capes e considera a obtenção do título suficiente para sua publicação na forma como se propõe a seção.

Suporte Financeiro: Capes, Novartis

Recebido: 29/09/2009

Aceito: 16/10/2009 